\title{
Theoretical model: analysing theoretically the air flow through car seat foam material
}

\author{
DOI: $10.35530 / 1 T \cdot 070.04 .1559 B$
}

\section{REZUMAT - ABSTRACT}

Model teoretic: analiza fluxului de aer prin materialul poros al scaunului auto

Confortul scaunelor auto reprezintă o caracteristică foarte importantă pentru autoturisme. Permeabilitatea la aer este direct legată de respirabilitatea și de confortul scaunelor auto. În acest studiu, spuma poliuretanică (PU) cu diverse orificii a scaunelor auto a fost testată din punctul de vedere al permeabilitătii la aer și simulată numeric pentru analiza fluxului de aer. Modelul geometriei detaliate oferă o imagine asupra fluxului de aer (presiune și viteză) prin volumul spumei, influențat de perforații și caneluri. Dar fenomenul simulat este diferit de cel măsurat. Fluxul de aer se formează in principal prin perforații (99\%), iar prin spumă este cu două unități mai scăzut. Folosind geometria omogenă cu permeabilitate "medie", parametrii au fost evaluați pe baza valorilor măsurate. Similitudinea fenomenului măsurat și simulat este foarte bună, cu o diferență de 1-5\%. Însă nu a fost posibil să se obțină detalii despre fluxul de aer în volumul de spumă.

Cuvinte-cheie: permeabilitate la aer, simulare numerică a fluxului de aer, material poros de grosime ridicată

\section{Theoretical model: analysing theoretically the air flow through car seat foam material}

Comfort of car seats is very important property for cars. Air permeability is directly related to the breath ability and comfort of car seats. In this research car seat Poly Urethane (PU) foam with different holes are tested for the air permeability and numerically simulated to predict the flow of air through thick foams. Model of detailed geometry gives good view about detailed flow field (pressure and velocity) in foam volume, influenced by perforations and grooves. But simulated flow is several times different from measured one. The main flow is through perforations (99\%) and flow through foam is of two orders lower. Using homogeneous geometry with "averaged" permeability parameters were evaluated from measured values. The coincidence of measured and simulated flow is very good, difference of $1-5 \%$. But it is not possible to get any details of flow in foam volume.

Keywords: air permeability, flow numerical simulation, thick foams

\section{INTRODUCTION}

Every middle-size vehicle uses between 12 and $14 \mathrm{~kg}$ of textile products, without including tire cords for pneumatic and fibres which are used in composite materials. The $65 \%$ of this quantity is used approximately in the interior (40 to $45 \mathrm{~m}^{2}$ of textile material per car) with a weight between 350 and $450 \mathrm{~g} / \mathrm{m}^{2}$ for the seats upholstery [1-4].

Textile advances in the automotive industry have been spearheaded by advances in science and technology of fibres and fabric/web forming technologies. These advances have led to the development of textiles and textile-based components for a broad variety of automotive applications which are capable of meeting the industry's tough specifications regarding high performance during use [5-10].

Development of car seat components. Parts, pieces and materials are orientated by the following criteria:

- Comfort

- Functionality

- Safety

- Economy

- Ecology
Car seat is perhaps, the most important part of the interior, it is the first element that the customer appreciates when he/she opens the door to look inside and it is the main interface between person and machine. The comfort is directly related to the air permeability of the car seat layers, if its possible to predict the air permeability of different layers then it's possible to evaluate the thermos physiological comfort of car seats.

\section{EXPERIMENTAL PART}

In this research work, classical PU foam of $30 \mathrm{~mm}$ and $5 \mathrm{~mm}$ thickness is used. The foams have area of $165 \mathrm{~cm}^{2}$. Figure 1 description of real sample of PU-foam with holes

\section{Air permeability of samples}

Concerning the terminology "permeability", used in textile technologies is defined as volume flow $\left(\mathrm{m}^{3} / \mathrm{s}\right)$ through the sample area $\left(\mathrm{m}^{2}\right)$, (i.e. $\left(\mathrm{m} / \mathrm{s}=\mathrm{m}^{3} / \mathrm{s} \cdot \mathrm{m}^{2}\right)$. In the fluid mechanics the same parameter is known as "volume flow density". 


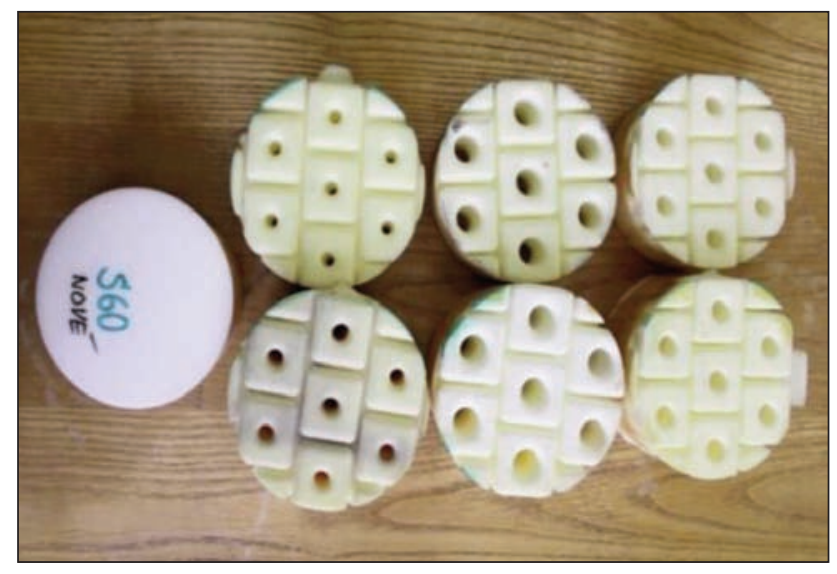

Fig. 1. Real samples of foams

It should be better to use the "mass flow density $\left(\mathrm{kg} / \mathrm{s} \cdot \mathrm{m}^{2}\right)$ ", which is independent on state quantities (pressure. temperature). This term is used in simulations below and in the fluid mechanics, too. Therefore for later comparison of measured and simulated flows the measured volume flows $(\mathrm{ml} / \mathrm{s})$ are recalculated into mass flows $(\mathrm{kg} / \mathrm{s})$.

Air permeability describes the rate of flow of a fluid through a porous material, and the mathematical expression is given by:

$$
q=\frac{Q}{A t}
$$

Where $q$ is rate of flow $(\mathrm{m} / \mathrm{s}), Q$ - volume of flow of fluid through the sample $\left(\mathrm{m}^{3}\right), t-$ time $(\mathrm{s})$ and $A-$ the cross-sectional area $\left(\mathrm{m}^{2}\right)$.

Textile material stands out as a unique class of porous media, which contain relatively high volume of air and very complex structure due to the random arrangement of fibres or pores. Air permeability is one of the most important properties of textile materials in many applications, Numerous researchers
Where $q$ is the rate of flow $(\mathrm{m} / \mathrm{s}), K_{p}$ - the flow permeability coefficient $\left(\mathrm{m}^{2}\right), \Delta p$ - the pressure gradient (pa), $\mu$ - the viscosity of the flow (pa.s), $L-$ the thickness of sample $(\mathrm{m}), \mathrm{Q}$ - the volume flowing in time $\left(\mathrm{m}^{3}\right), A$ - the cross-section area $\left(\mathrm{m}^{2}\right)$ where flow goes through, $t$ - time (s).

As explained in the Literature review part that the air flow and the water vapor permeability are the connected properties. This gives us the idea to theoretically analyses the flow of air through the textile layers and predict the performance of the car seat materials. For this research the software FLUENT is used for the theoretical analyses and the results are compared with the experimental results.

The permeability is defined as the volume flow $V$ $\left(\mathrm{m}^{3} / \mathrm{s}\right)$ through the cross-section of the sample $S\left(\mathrm{~m}^{2}\right)$. So the permeability is identical with flow velocity through tested sample:

$$
w=\frac{V}{S}(\mathrm{~m} / \mathrm{s})
$$

\section{APPLICATION OF MEASURED DATA}

\section{Used samples}

Thick PU cushion part of the car seat is used for this research. The classical foam and the foam with the perforation are used for this research the properties are shown in table 1 below.

The hole dimensions of used samples are shown in figure 2 .

\section{Measured air permeability}

The air permeability of the samples are tested under different pressure difference by standard method ISO standard 9237. Results are shown below. It is quite obvious that the PU-foam without holes is almost impermeable and the flow increases with the size of hole.

\begin{tabular}{|c|c|c|c|c|c|c|}
\hline \multicolumn{7}{|c|}{ PU-FOAM PROPERTIES FOR THE NUMERICAL SIMULATION } \\
\hline Samples & $\begin{array}{c}\text { Foam } \\
\text { thickness } \\
(\mathbf{m m})\end{array}$ & $\begin{array}{c}\text { Number } \\
\text { of holes }\end{array}$ & $\begin{array}{c}\text { Hole } \\
\text { diameter } \\
(\mathbf{m m})\end{array}$ & $\begin{array}{c}\text { Total area of } \\
\text { foam sample } \\
\left(\mathbf{m m}^{2}\right)\end{array}$ & $\begin{array}{c}\text { Area } \\
\text { of holes } \\
\left(\mathbf{m m}^{2}\right)\end{array}$ & $\begin{array}{c}\text { Area of solid } \\
\text { foam } \\
\left(\mathbf{m m}^{2}\right)\end{array}$ \\
\hline A & 60 & 0 & 0 & 16505 & 0 & 16505 \\
\hline A1 & 60 & 7 & 10 & 16505 & 550 & 15955 \\
\hline A2 & 60 & 7 & 15 & 16505 & 1236 & 15268 \\
\hline A3 & 60 & 7 & 20 & 16505 & 2198 & 14307 \\
\hline
\end{tabular}

have worked on the air permeability of non-woven fabrics in both experiment [2-4] and analytical prediction [5-7]. Darcy derived an equation for calculating the air permeability based on hydraulic radius theory, which states that rate of flow is directly proportional to the pressure gradient causing the flow. The equation is as follows:

$$
Q=\frac{A \cdot t\left(K_{p} \cdot \Delta P\right)}{\mu L}
$$

AIR PERMEABILITY VALUES AT DIFFERENT PRESSURE

\begin{tabular}{|c|c|c|c|c|}
\hline \multirow{2}{*}{$\begin{array}{c}\text { Press } \\
(\mathbf{P a})\end{array}$} & \multicolumn{4}{|c|}{ Unit (mL/sec) } \\
\cline { 2 - 5 } & $\mathrm{F} 0$ & $\mathrm{~F} 1$ & $\mathrm{~F} 2$ & $\mathrm{~F} 3$ \\
\hline 1.1 & 0.2 & 19 & 43 & 60 \\
\hline 1.5 & 0.6 & 45 & 92 & 140 \\
\hline 2 & 1.1 & 70 & 125 & 200 \\
\hline 2.2 & 1.25 & 80 & 145 & 235 \\
\hline
\end{tabular}




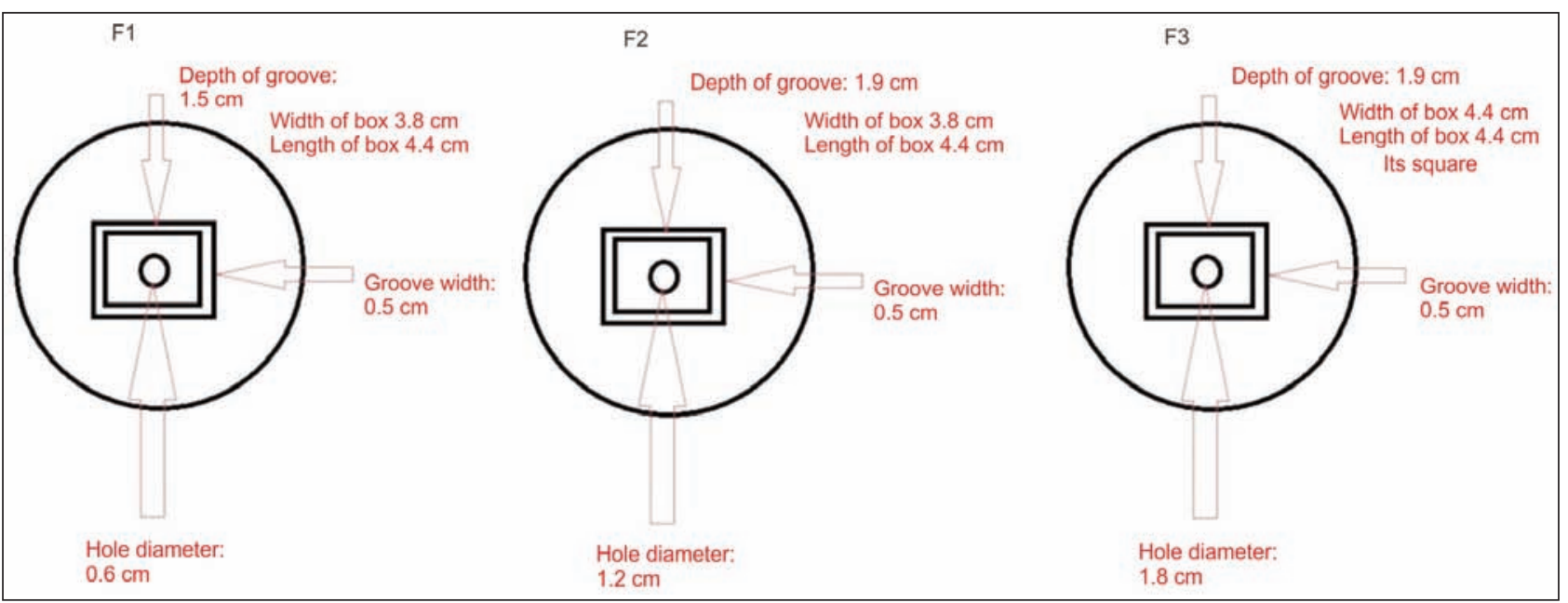

Fig. 2. Description of real sample of PU-foam with holes

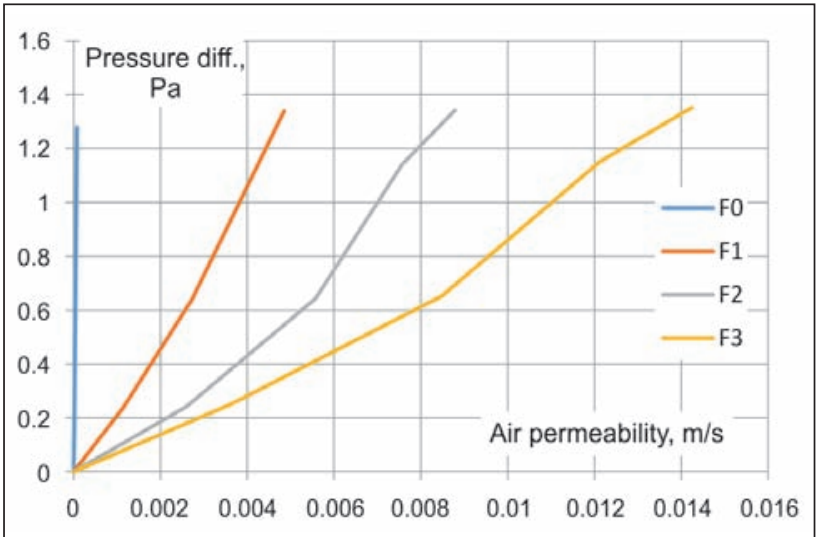

Fig. 3. Air permeability at different pressure

Permeability of the classical foam (F0) is 64-188 times lower permeable than cases F1-F3 as shown in figure 3.

\section{Adaptation of measured data}

Following evaluation of measured data and determination of permeability parameters is explained for the case F0 (full foam) only. Next cases (F1-F3) are created as foam bodies (F0) with additional perforations and grooves.

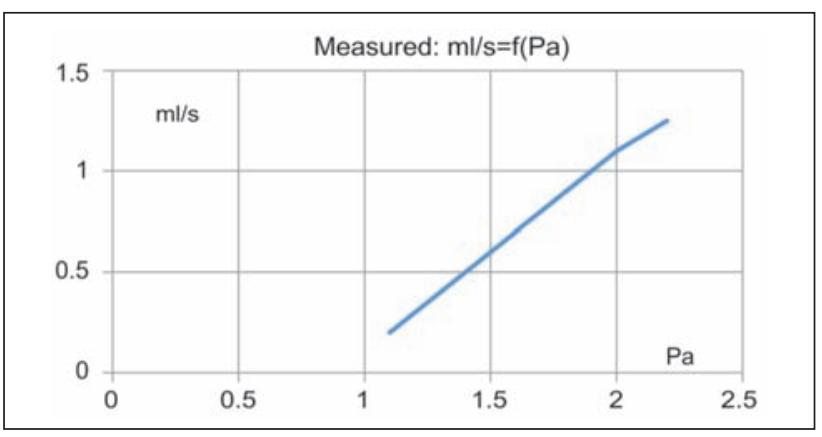

Fig. 4. Measured values of volume flow

The flow starts at $1 \mathrm{~Pa}$ approx. - from the physical point of view it is not precise - and might be influenced

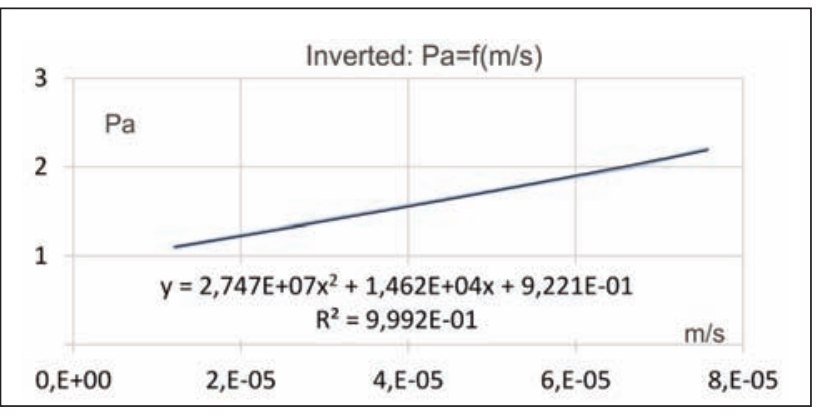

Fig. 5. Recalculation in permeability

by the insensitivity of measuring device under $1 \mathrm{~Pa}$ pressure.

Measured volume flows $(\mathrm{ml} / \mathrm{s})$ are recalculated in permeability $\mathrm{m} / \mathrm{s}\left(=\mathrm{m}^{3} / \mathrm{s} \cdot \mathrm{m}^{2}\right)$ and inverted.

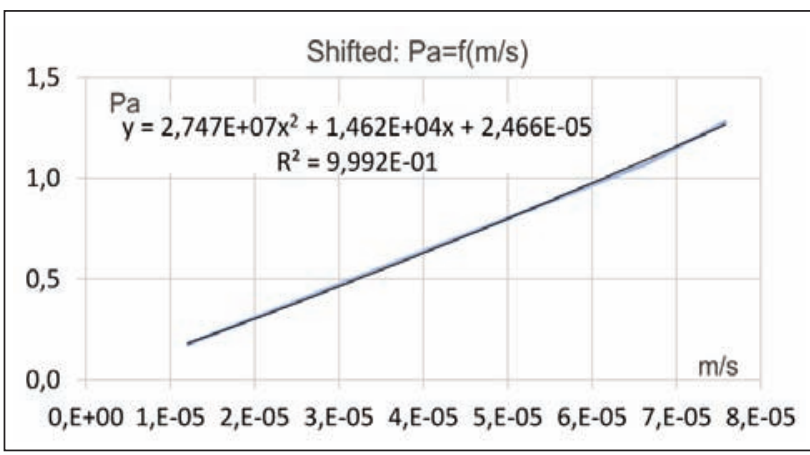

Fig. 6. Shifted values

Values are shifted, to correct any measuring error (at zero mass flow the flow resistance must be zero, too). After such correction the permeability parameters can be determined.

\section{Permeability parameters determination}

The method is described in [10] for so-called "pressure jump" in one-dimensional flow and thin porous layer. Here is the method used for so-called "porous zone", generally as the flow in 3-dimensional permeable volume (thick porous layer). Theoretical formulas 
[10] are analogous, so it is supposed to use the same procedure in 3D for homogenous permeability. Generally, the qualitative results (images of flow fields), are all right, but the quantitative results of simulations ( $\mathrm{m} / \mathrm{s}, \mathrm{kg} / \mathrm{s}$ etc.) are different from measured values.

The permeability of the observed layer is given by its flow resistance. This resistance consists in general from the linear term, typical for instance for small velocities (so-called Darcy's law) and from the quadratic term, typical for flow around bodies or through channels (Weissbach's or Moody's law):

$$
\Delta p=C_{2} \cdot \frac{\rho}{2} \cdot t \cdot w^{2}+\frac{\mu}{\alpha \cdot t \cdot w}
$$

where:

$w=V / S(\mathrm{~m} / \mathrm{s})$ is flow velocity;

$V\left(\mathrm{~m}^{3} / \mathrm{s}\right) \quad-$ volume flow;

$S\left(\mathrm{~m}^{2}\right) \quad-$ flow cross-section (here $20 \mathrm{~cm}^{2}$ );

$t(\mathrm{~m}) \quad-$ layer thickness;

$\rho\left(\mathrm{kg} / \mathrm{m}^{3}\right)$ - medium density (for atmospheric air $\left.1,2 \mathrm{~kg} / \mathrm{m}^{3}\right)$;

$\mu\left(\mathrm{m}^{2} / \mathrm{s}\right) \quad-$ viscosity (for air $\left.1,806 \mathrm{e}-5\right)$;

$\alpha\left(m^{2}\right), C_{2}(1 / m)-$ unknown permeability parameters [10].

Two unknown permeability parameters $\alpha, C_{2}$, depending on the layer structure, can be determined from the experimental data.

In previous graphs the function $\mathrm{Pa}=f(\mathrm{~m} / \mathrm{s})$ is substituted by quadratic function with very high correlation coefficient. Parameters of this substitution are used as follows:

Comparing the formula for pressure resistance as function of velocity:

$$
\Delta p=A \cdot w^{2}+B \cdot w+C
$$

From Eq. 5 we can determine two unknown permeability parameters $C_{2}$, $\alpha$ from:

$$
\begin{aligned}
& A=C_{2} \cdot \frac{\rho}{2} \cdot t \\
& B=\frac{\mu}{\alpha t}
\end{aligned}
$$

where $A, B$ (and $C$, which should be equal zero) are parameters of the quadratic substitution.

For given values of

$$
\begin{array}{ll}
\text { thickness } & t=0,03 \mathrm{~m}, \\
\text { air density } & \rho=1,2 \mathrm{~kg} / \mathrm{m}^{3}, \\
\text { dynamic viscosity } & \mu=1,806 \mathrm{e}-5 \text { (Pa.s) }
\end{array}
$$

the permeability parameters are as follows:

$$
\begin{aligned}
& C_{2}=\frac{2 \cdot A}{\rho \cdot t} \\
& \alpha=\frac{\mu \cdot t}{B}
\end{aligned}
$$

Determined permeability parameters for F0 are

$$
C_{2}=1,526 \mathrm{e}+09(1 / \mathrm{m}), \quad 1 / \alpha=2,698 \mathrm{e}+10\left(1 / \mathrm{m}^{2}\right)
$$

For testing purposes the foam F0 is used, only, foams F1, F2, F3 are not evaluated here, because the relevant models are created as foam body (permeability parameters of F0) with perforations and grooves.

\section{NUMERICAL SIMULATIONS}

The basic model of the numerical simulation was designed and the software was run with the input equation and the parameters form the experimental results. The basic model is shown in figure 7 .

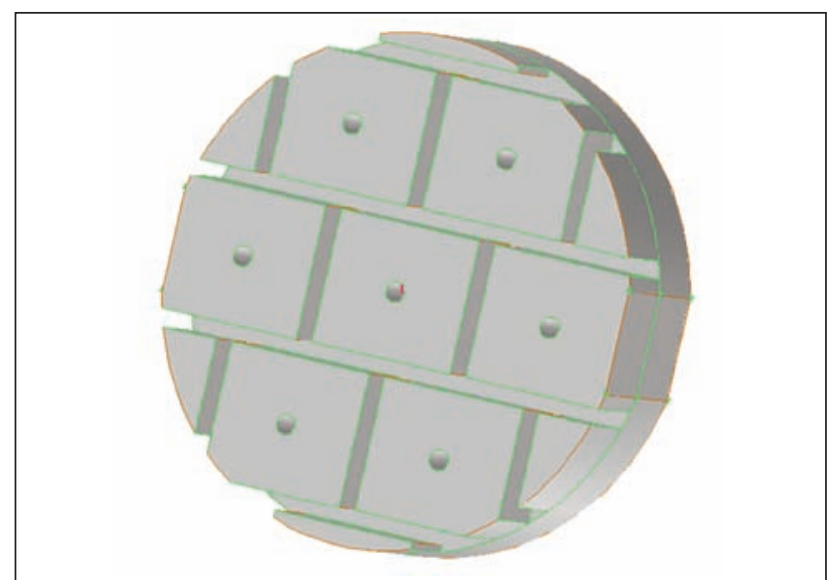

Fig. 7. Basic model of numerical simulation

The main results of the numerical simulation are shown in the table 3. Differences between flows of inlet and outlet are not important. Even if the holes area is $1,1 \%$ of the total area of sample, the main flow is going through holes and the flow through the foam material is less than $1 \%$ approximately. It could be stated that the foam is practically impermeable and used as compressible cushion.

Table 3

INLET AND OUTLET PREDICTION OF LOW

\begin{tabular}{|c|l|c|c|c|c|c|}
\hline \multirow{2}{*}{ Samples } & \multicolumn{2}{c|}{ Area } & \multicolumn{2}{c|}{ Mass flow } & Measured \\
\cline { 3 - 7 } & & $\left(\mathbf{m}^{2}\right)$ & $(\%)$ & $\mathbf{( k g / s )}$ & $\mathbf{( \% )}$ & $\mathbf{( k g / s )}$ \\
\hline \multirow{4}{*}{ inlet } & foam & 0.012858 & 78.2 & $0.92794 \mathrm{e}-6$ & 0.3 & \\
\cline { 2 - 7 } & grooves & 0.003415 & 20.8 & $2.24480 \mathrm{e}-6$ & 0.8 & \\
\cline { 2 - 7 } & holes & 0.000178 & 1.1 & $2.80000 \mathrm{e}-4$ & 98.8 & \\
\cline { 2 - 7 } & sum & 0.016452 & & $2.83300 \mathrm{e}-4$ & & $0.415 \mathrm{e}-4$ \\
\hline \multirow{4}{*}{ outlet } & foam & 0.016273 & 98.9 & $2.07184 \mathrm{e}-6$ & 0.7 & \\
\cline { 2 - 7 } & holes & 0.000178 & 1.1 & $2.81000 \mathrm{e}-4$ & 99.2 & \\
\cline { 2 - 7 } & sum & 0.016451 & & $2.83300 \mathrm{e}-4$ & & $0.415 \mathrm{e}-4$ \\
\hline
\end{tabular}

Next serial of flow fields presents main qualitative results. To get full details of individual flow fields different scales are used. The model is shown with different graphical representation.

Pressure is penetrating into blind/closed grooves, stopped at the groove bottom. In continuous holes the value is low due to conversion of the pressure into velocity.

The main flow is through holes, the flow through foam is extremely low. 


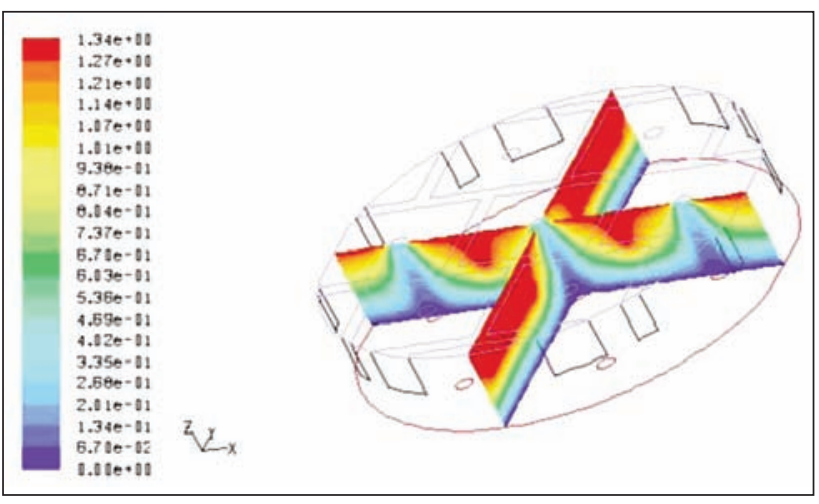

Fig. 8. Pressure field - axial cross sections

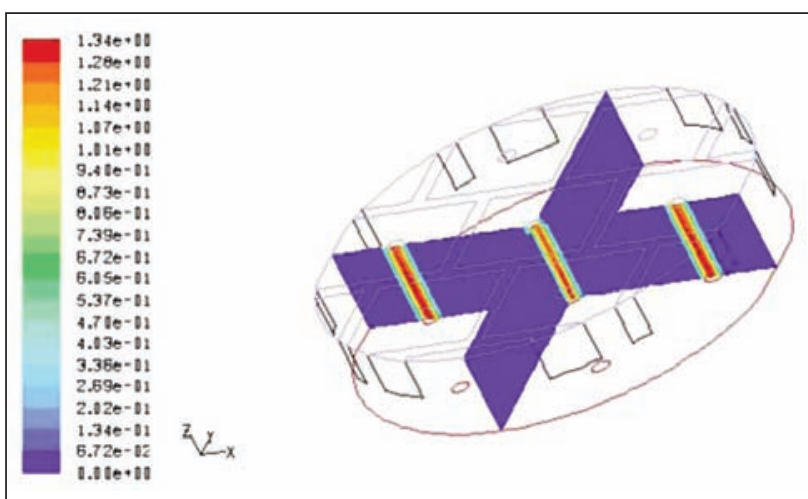

Fig. 9. Velocity field - axial cross sections - full scale

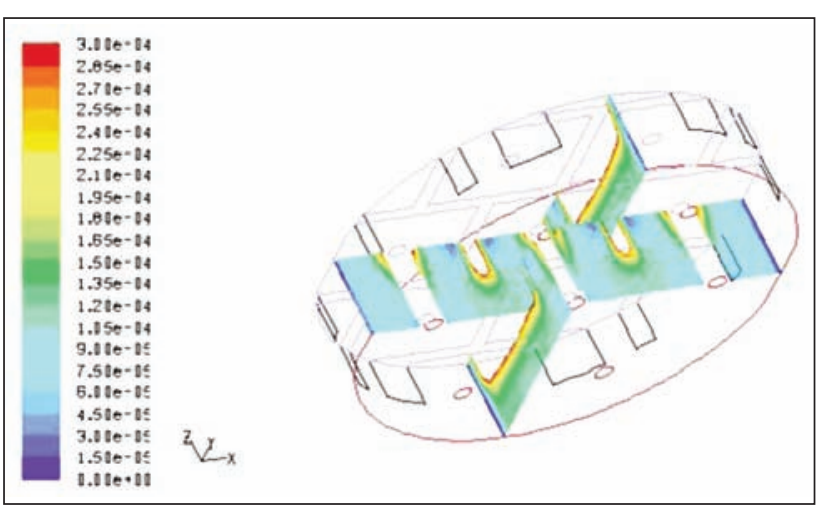

Fig. 10. Axial cross sections. suppressed scale

Flow in grooves is stopped at the groove bottom and slightly is penetrating into foam volume. Simulation can explain details of flow in permeable volume.

The velocity field at the inlet plane is maximum in the holes.

Local maximum in larger cross sections (in T-junctions). Individual irregularities could be suppressed by finer mesh.

Figures 8-13 show flow fields from main qualitative results. To get full details of individual flow fields different scales are used. The model is shown with different graphical representation.

\section{Foam under load (pressed)}

Hypothesis for this part of the model is that if the foam is pressed then the foam volume by $50 \%$ in the

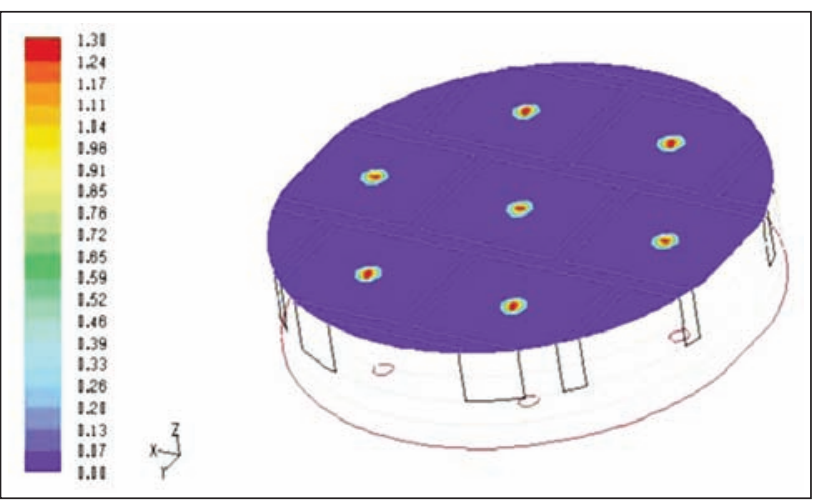

Fig. 11. Velocity field at the inlet plane - full scale. Maximum in holes

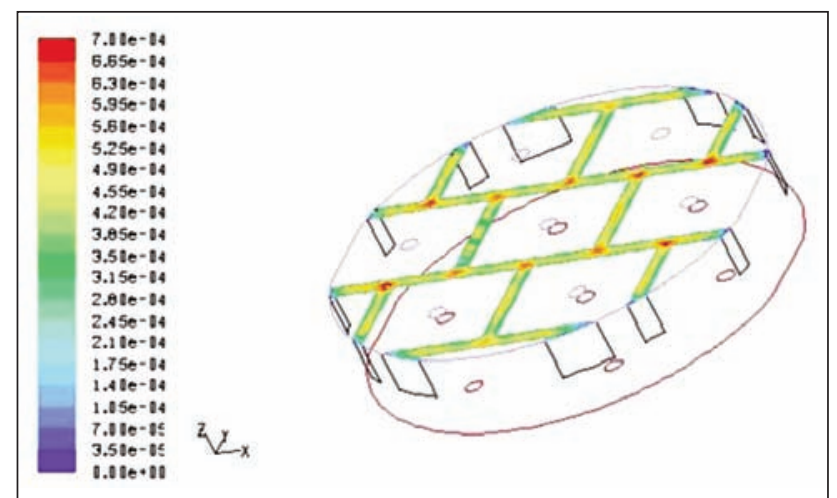

Fig. 12. Velocity field in grooves at the inlet side - suppressed scale

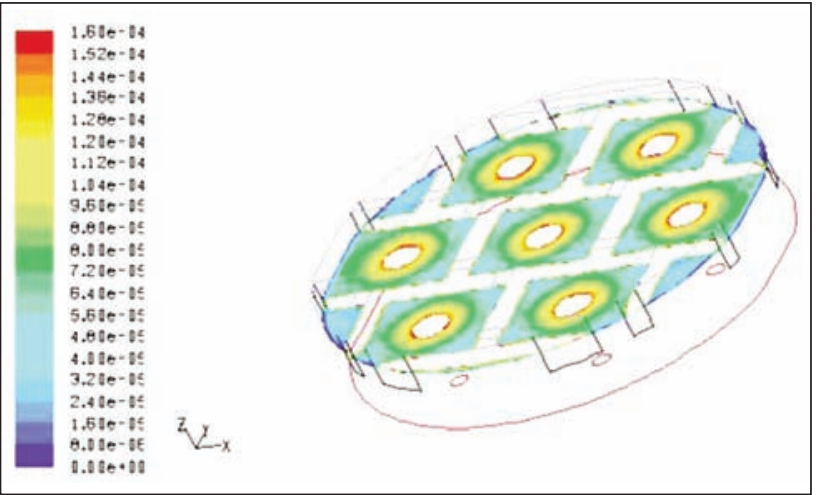

Fig. 13. Velocity field $7.5 \mathrm{~mm}$ from the inlet side - suppressed scale

flow direction. The inner permeable cells are also pressed by $50 \%$ too, so eventually the permeability is also decreasing by $50 \%$ too. And more, it is supposed that geometry deformation is along the axis of deformation and there is no abnormal shape or buckling in cross directions.

For simple verification the model geometry remains the same. New parameters of permeability are determined as in the table 4 from the condition of $50 \%$ of measured flow.

Results are summarized in the tabel 5 where original mass flows mass flows through foam and grooves is decreased by $28 \%$ and $27 \%$ respectively of original values. It means from $1 \%$ of the whole flow to $0.3 \%$ 


\begin{tabular}{|c|c|c|c|}
\hline & & & Table \\
\hline \multicolumn{4}{|c|}{$\begin{array}{l}\text { PERMEABILITY PARAMETERS FOR 50\% FLOW } \\
\text { (DUE TO FOAM PRESSING) }\end{array}$} \\
\hline & $\mathrm{C} 2$ & $\alpha\left(m^{2}\right)$ & $1 / \alpha\left(1 / \mathrm{m}^{2}\right)$ \\
\hline Fo & $1.111 \mathrm{E}+10$ & 7.052E-12 & $1.418 \mathrm{E}+11$ \\
\hline
\end{tabular}

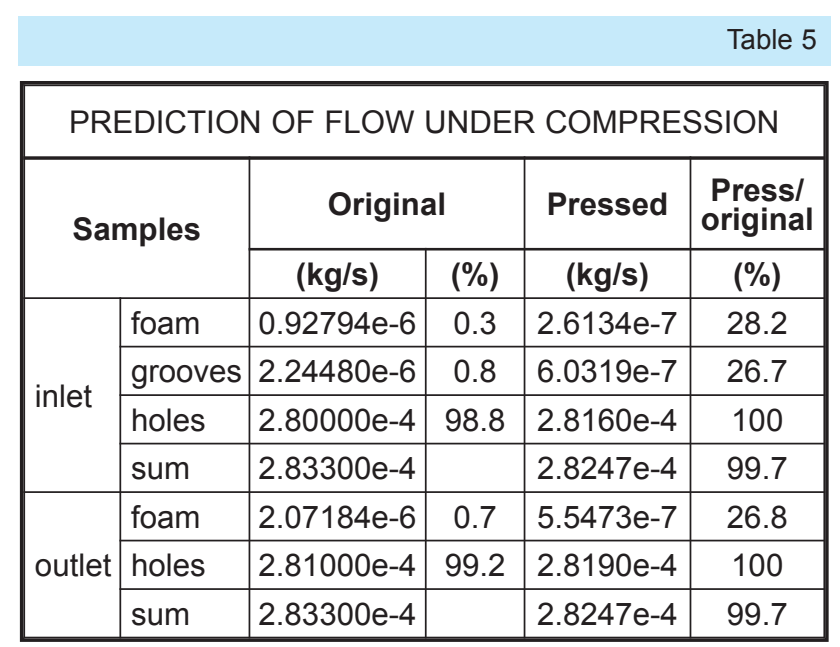

approximately. It has not any influence on the flow through holes, as it represents $99 \%$ of the whole flow and some small flow changes in foam and grooves does not have any influence.

\section{Testing cases of full foams}

Two cases of full foams (F0, F1) were solved; differences between simulated and measured mass flows are $1 \%-5 \%$, only. The detailed geometry gives good imagination about fine details of velocity and pressure field in the foam volume, the main flow is going through perforations.

On the other side, the simple model of "foam" presents the average flow, regardless of perforations and grooves. Therefore the correlation of measured and simulated mass flow is very good, but details of flow field inside the foam volume cannot be perceived.

Figure 14 shows differences between mass flows in $\mathrm{F} 0$ and $\mathrm{F} 1$.

\section{CONCLUSION}

The results from many solved cases of numerical flow simulation in the PU-foam with the perforation can be summarized as below

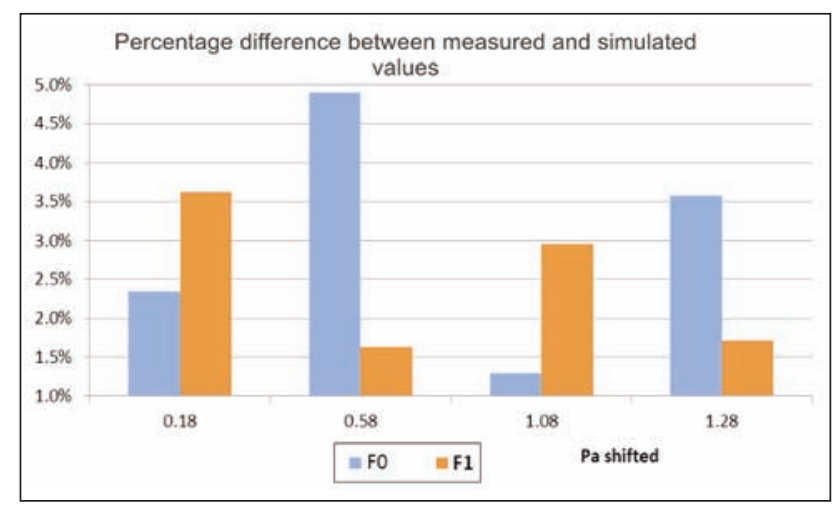

Fig. 14. Difference between measured and simulated mass flows for foams F0 and F1

1. It is possible to state that the method of numerical flow simulation used for the air permeability through porous medium gives a good imagination about the main features of the flow field in complicated structures, considering both continuous and blind air volumes and foam volumes (for instance the pressure or velocity distribution. concentration of the flow in the foam area around individual holes and grooves, flow spreading from the groove bottom in foam. flows in foam. induced by strong flow in adjoining holes etc.).

2. Using the simple geometry of full foam (case F0). The difference between mass flows measured and simulated is very low (few percentage only). In case of F0 there is not much flow of air. Therefore it could be stated that strong flows through perforated holes have the main effect in total mass flow balance and the flow through foam is negligible.

3. Influence of pressed foam layer has practically no influence on the total flow. According to previous points. The main part is flowing through "empty" holes practically without resistance (compared with reduced flow through the foam volume. due to the higher foam resistance after pressing).

The simulation can be used to test it with even more added layers and check the permeability of sandwich car seat covers.

\section{ACKNOWLEDGEMENT}

This work was supported by the Ministry of Education, Youth and Sports of the Czech Republic and the European Union - European Structural and Investment funds in the frames of operational program Research, Development and Education - Project Hybrid Materials for Hierarchical Structures (HyHi, Reg. No. CZ.02.1.01/0.0/16_019/0000843).

\section{BIBLIOGRAPHY}

[1] Jerkovic, I., Pallares, J.M., Capdevila, X., Study of the abrasion resistance in the upholstery of automobile seats, In: AUTEX Research Journal, 2010, 10, pp. 14-20

[2] Ford's Sustainable Materials Strategy, Feb. 2012, Excess date: 30.03.2017 http://media.ford.com/images/10031/ Ford_Sustainable_Materials_Fact_Sheet.pdf

[3] Environmental \& Social Report, 2005, Excess date 30.03.2017 http://www.toyotaglobal.com/sustainability/report/ sr/05/pdf/eco_04.pdf 
[4] Söderbaum, E., Requirements for automotive textiles - a car producer's view in Textile advances in the automotive industry, In: Woodhead Publishing in Textiles, 2008, 79, pp. 3-15, ISBN: 978-1-84569-331-2

[5] Havelka, A., Glombiková, V., Mazari, F.B., Monitoring thermophysiological comfort in the interlayer betweendriver and the carseat. In: Vlakna a Textil, 2015, (3/4), pp. 40-45, ISSN 13350617 (Scopus)

[6] Slater, K., Human Comfort, In: Thomas Publisher, Springfield, IL, USA, 1985, 4, ISBN:0398051283

[7] Choudhary, A.K.R., Majumdar, P.K., Datta, C., Factors affecting comfort: Human physiology and role of clothing, Improving Comfort in Clothing, In: Wood Head Publishing, 2011, pp. 1-57, ISBN: 1845695399

[8] Tugrul Ogulata, R., The effect of thermal insulation of clothing on human thermal comfort, In: Fibres \& Textiles in Eastern Europe, 2007, 61(2), pp. 67-72

[9] Das, A., Alagirusamy, R., Science in clothing comfort, In: Wood Head Publishing, UK, 2011, ISBN 1845697898

[10] Sharma, S., Topical drug delivery systems: A review. Available, from: http://www.pharmainfo.net. 2016

\section{Authors:}

MAZARI FUNDA BUYUK ${ }^{1}$, MAZARI ADNAN ${ }^{1}$, HAVELKA ANTONIN¹, ADAMEK KAREL ${ }^{2}$

${ }^{1}$ Technical University of Liberec, Faculty of Textile Engineering, Department of Textile Clothing,

Studentska 2, Liberec, 461 17, Czech Republic

${ }^{2}$ VúTS Liberec, Svárovská 619, CZ-46119 Liberec

Corresponding author:

MAZARI FUNDA BUYUK

e-mail: fundabuyuk@hotmail.com 